\title{
飲料缶内面塗膜のレモンフレーバーに与える 影響の統計的解析
}

\author{
夏堀育子* ・島田博彰*
}

\section{Evaluation of Influence of Plastic Films Used for Interior Can Coating on Lemon Flavor by Using Multivariate Analysis}

\author{
Ikuko Natsubori ${ }^{*}$ and Hiroaki Shimada ${ }^{*}$ \\ Central Research Laboratories, Dainippon Ink and Chemicals, Inc., \\ 631, Sakado, Sakura-shi, Chiba-ken 285
}

\begin{abstract}
Various plastic films coated and baked on aluminum foil were individually immersed in lemon-flavored aqueous solution in sealed glass jars. Every solution was pasteurized and stored at $25^{\circ} \mathrm{C}$ for one week. The volatiles in the lemon flavor solution were concentrated with chromosorb 106 and the subsequent ether elution. Then the volatiles were quantitatively analyzed by GC-MS. Cluster analysis and principal component analysis were applied for the obtained $17 \mathrm{GC}$ peak area data. As the result of cluster analysis, the films were roughly classified into two groups corresponding to their resin types (Waterborne or Solventborne). As the result of principal component analysis, the films were roughly classified corresponding to their resin types and resin compositions. Total amount of flavor compounds contributed to the first principal component and amount of terpinen-4-ol or $\alpha$-terpineol known as off-flavor compounds of Satsuma Mandarin Juice contributed to the second principal component.

(Received Dec. 20, 1992)
\end{abstract}

飲料年は，自動販売機の普及と共にその簡便性やファ ッション性から，日本経済の高度成長を背景にして多量 に用いられるようになり ${ }^{1)}$ ，国内で年間約 300 億缶も消 費されるに至っている2゙．ところで，飲料缶には缶材の 防食之内容物保持の目的で，内面に塗料が塗装されてい る. そしてここ数年 “一億総グルメ化”という言葉に象 徴されるように，人々の味や香り(フレーバー）に対す る関心が高まっている風潮を反映し，飲料缶内面塗料に 対してもより高度なフレーバー保持性が求められてきて いる.

しかしながら，夹際の飲料午内容物におけるフレーバ 一変化は非常に複雑であり，フレーバー保持性を単純な 定量的分析手法によって評価することは困難である。な ぜならフレーバー成分は元来保存するだけでも大きな変
化を起こす上に，容器材料の一つである叙膜へ収着した り, 容器材料や容器材料から溶出した成分の関与により,

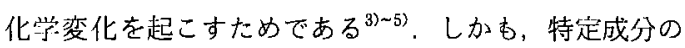
增加、滅少ばかりでなく，多数のフレーバー成分からな る調利が崩されることによってあフレーバーは影響を受 ける.したがって現在, フレーバー保持性の評価は，専 ら食品メーカーの専門パネリストによる官能検查に上っ て行われている。こうした現状から，飲料年の製造，開 発に携わる分野の人々にとっては，人の感覚に代わる客 観的フレーバー保持性評価法の確立が待たれている。

香りの分析に関する報文は近年非常に增えてきている 香気成分の定性データに関するものが主流ではあるが， 多変量解析等を用いて統計的にデータ処理することでサ ンプルを評価する(例) 20) 多く見られるようになって

*大日本インキ化学工業(株)総合研究所（干285 T葉県佐倉市坂戸 631） 
きた.しかし包装材との関連に関して扱ったものとなる とごく少ない(5) 211)。そこで，本研究ではフレーバー成 分組成の比較的単純なレモンフレーバーを選び, 種々の 塗膜との関連についての定量的な GC-MS 分析データ を収集し，それらを統計解析することにより，フレーバ 一成分上塗膜との関係についての知見を得ることを目的 とした。

\section{実 験 方 法}

\section{1. 試 料}

1) 試料溶液

レモンフレーバー水溶液は，小川香料(株)上り入手し た天然レモンエッセンスの原液を蒸留水で $1 / 200$ に希勫 して用いた，主たる含有成分は $\alpha$ 一ピネン， $\beta$-ピネン，

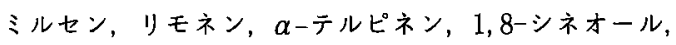

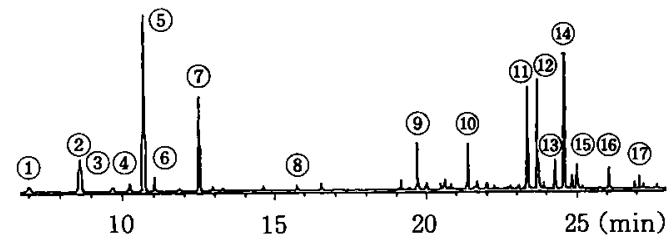

図 1 レモンフレーバーのガスクロマトグラム

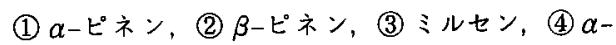
テルピネン, (5) リモネン, (6) $1,8^{-}$シネオール, (7) $\mathrm{p}$ サイメン, (8)ノナナール, (9)リナロール, (10) テルピネンー4-オール, (11) ネラール, (12) $\alpha-テ$ ルピネオール, (13)ネリルアセテート, (14)ゲラニ アール, (15) ゲラニルアセテート, (16)ネロール, (17) ゲラニオール p-サイメン，ノナナール，リナロール，テルピネン-4オール，ネラール，ネリルアセテート，ゲラニアール， ゲラニルアセテート，ネロール，ゲラニオール， $\alpha-$ ネ ルピネオールの 17 種である. GC チャートを Fig. 1 に示す。尚, 加熱処理前の溶液 $\mathrm{pH}$ は室温で 5.3 , 溶存 酸素量は飽和溶解量の約 $9 \mathrm{ppm}$ であった。

2) 試料塗膜

夷験に使用した 14 種類の現行内面染料を Table 1 に 示す，塗膜はアルミ板に両面塗装後，端部を補正し，規 定の焼き付けを行い作製した。

淕膜面積は $200 \mathrm{~cm}^{2}$ ，膜厚は約 $4 \mu \mathrm{m}$ である.

\section{2. 試料調製}

$300 \mathrm{~m} l$ 耐熱扎じロガラスビンにレモンフレーバー水 溶液 $270 \mathrm{~m} l$, を入れ，続いて各塗膜を 4 枚づつ浸漬, 密閉, $90^{\circ} \mathrm{C}$ 温水 8 分 (液温 : 約 $75^{\circ} \mathrm{C}$ ), $75^{\circ} \mathrm{C}$ 温水 10 分,

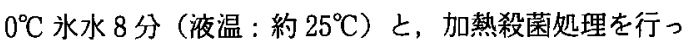
た.この好理条件は, 食品メーカーにおいて柑橧系ジュ ースに適用されている“コールドパック条件”をもとに 設定したものである.それらを $25^{\circ} \mathrm{C}$ で一週間遮光保存 したものについてフレーバー成分を回収し，GC-MS 分析を行った。 また，塗膜を浸漬しない溶液試料（ブラ ンク）についてむ，加熱処理後 $25^{\circ} \mathrm{C}$ で一週間遮光保存 したものを GC-MS 分析した.

\section{3. フレーバー成分の回収及び濃縮法}

レモンフレーバー水溶液を，Fig. 2 に示すような直 径 $2 \mathrm{~cm}$, 長さ $10 \mathrm{~cm}$ のカムに通してポリマービー ズにフレーバー成分を吸着させた後，エーテル $40 \mathrm{ml}$ によりフレーバー成分を回収した，ポリマービーズには， フルーツ様フレーバー溶液の成分回収率が良好であると 報告されている ${ }^{22)}$ Chromosorb 106 (60-80メッシュ)

表 1 塗 料 の 分 類

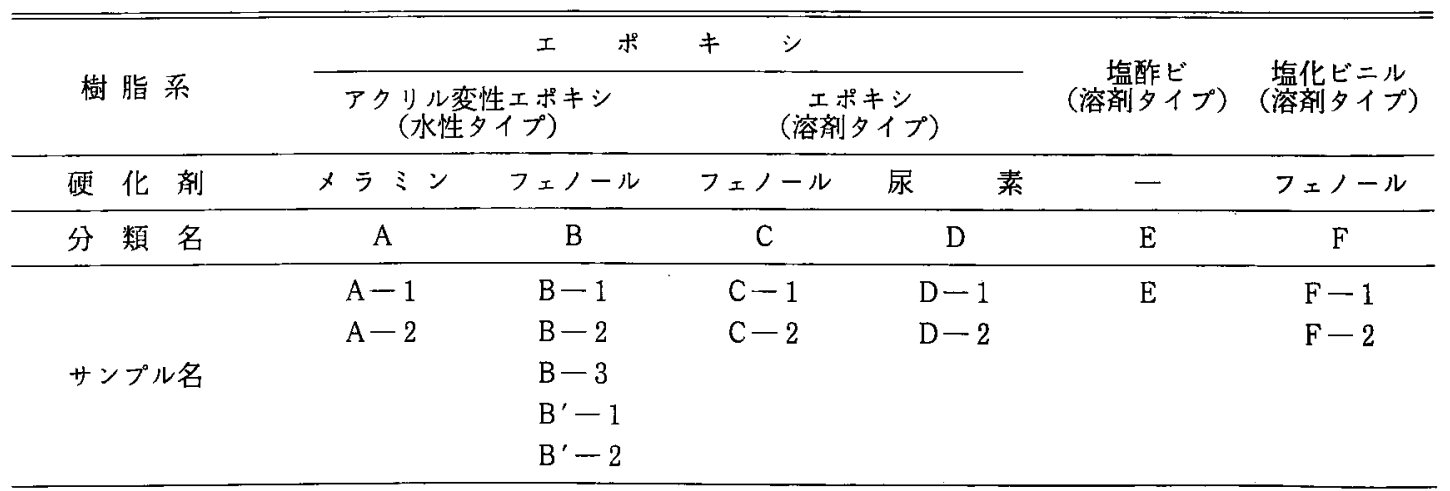

○分類 B 中の B と $\mathrm{B}^{\prime}$ では，樹脂組成が異なる. 


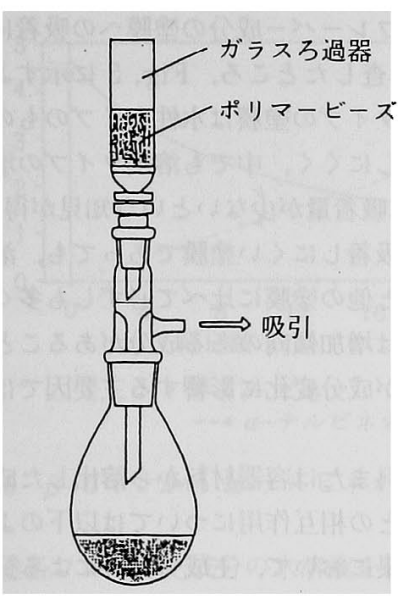

図 2 ポリマービーズを用いる香気成分の吸着装置

を $3.5 \mathrm{~g}$ 用いた。ポリマービーズの精製及び洗浄は文 献 22)を参考に行った，得られた抽出液を，無水硫酸ナ トリウムにて一尽夜脱水後, Kuderna-Danish 濃縮装 置を用いて約 $8 \mathrm{ml}$ まで濃縮し, 内標準として $40 \mathrm{ppm}$ のシクロヘキシルアセテートエーテル溶液を $2 \mathrm{ml}$ 添加 し， GC-MS 分析サンプルとした．このサンプルは各 塗膜につき 3 個づつ調製し，分析を行った.

\section{4. 分析機器及ひ条件}

GC-MS は，ヒューレットパッカード社製の GC : HP 5890 A 及び MS : HP 5970 B を用いた。 カラムは $\mathrm{J} \& \mathrm{~W}$ 社製の $\mathrm{DB}-\mathrm{WAX}$, 内径: $0.25 \mathrm{~mm}$, 液相膜厚 $0.25 \mu \mathrm{m}$ ，長さ： $60 \mathrm{~m}$ を用いた。キャリアーガスには $\mathrm{He}$ を用い，線速度 : $25 \mathrm{~cm} / \mathrm{sec}$ に設定した，GC 注入 口温度 : $200^{\circ} \mathrm{C}$, 検出器温度 : $280^{\circ} \mathrm{C}$, カラム温度 : $29 \sim$ $60^{\circ} \mathrm{C}$ が $20^{\circ} \mathrm{C} / \mathrm{min}, 60 \sim 200^{\circ} \mathrm{C}$ が $5^{\circ} \mathrm{C} / \mathrm{min}$ の昇温, さ らに $200^{\circ} \mathrm{C}$ て $15 \mathrm{~min}$ 保持の条件で分析した. MS の分. 析モードは定量感度の良いSIM モードとし，モニター イオンの質量数には， $56,57,68,69,70,71,82,84$, 88，93を用いた。

\section{5. テータ処理}

【GC-MS 面積比データ】

GC-MS 分析から得られたビークのうち，主要な 17 ピークについて, 各々面積比 $\mathrm{A} / \mathrm{Ai}$ （各ピーク面積值／ 内標準ピーク面積値) の3サンプルの平均值を求めた.

\section{【統計解析】}

各サンプルのピーク面積比平均值をクラスター分析と 主成分分析 ${ }^{23)}$ 24) に上り解析し，深膜の分類を試みた. これらの解析には文献 ${ }^{25)}$ を参考に作成したパンコンプ ログラムを使用した。 クラスター分析には, 類似の度合
いを表す指標としてユークリッド平方距離を用い，クラ スター間距離の定義には最長距離法を用いた階層的方法 を適用した。

\section{実験結果及び考察}

\section{1. クラスター分析結果}

Fig. 3 に分析結果のデンドログラムを示す．縦軸は クラスターを形成したサンプル間の非類似度（距離）を 示す.

塗膜サンプルは，一部例外があるものの，塗料形態が 水性タイプのもの之，溶剂タイプのものの 2 グループに 分類された。

この結果から, 水性タイプあるいは溶剤タイプといっ た塗料形態が同様な塗膜は，レモンフレーバー成分に対 して類似した影響を与える傾向があると考えられる。

\section{2. 主成分分析結果}

Fig. 4 に主成分分析結果を示す. 横軸は第一主成分 軸であり，サンプルに関する全情報の約 $42 \%$ を要約し ている，縦軸は第二主成分軸であり，全情報の約 $22 \%$ を要約している.

塗膜サンプルは第二主成分軸のゼロを境にして，ほぼ 以下のような樹脂のタイプからなるグループに分けられ た.

(1) 溶剤タイプの樹脂と一部の水性タイプのアクリル 変性エポキシ樹脂グループ

(2) 水性タイプのアクリル変性エポキシ樹脂グループ さらに，第一主成分軸に注目すると，(1)のグループ

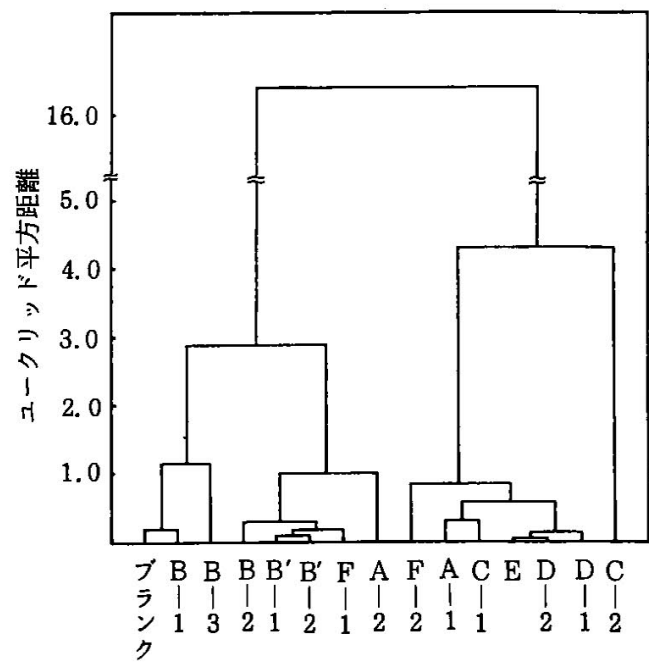

図 3 クラスター分析結果 


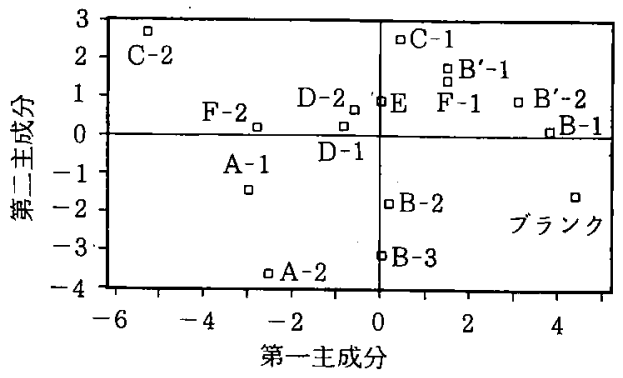

図 4 主成分分析結果

は，水性タイプのアクリル変性エポキシ樹脂が，全て第 一主成分軸のプラス倒に位置しており，溶剤タイプの樹 脂とほぼ完全に分離する結果となった。この水性タイプ のアクリル変性エポキシ樹脂と (2)のものとでは，樹脂 組成が異なっている.

これらの解析結果により，溶剤タイプの樹脂と水性夕 イプの樹脂ではフレーバー保持性が異なること，また， 同じ水性タイプの樹脂でも，樹脂組成の違いによって異 なる影響を示すすのがあることが推察される。

軸に寄与する要因を考察すると，第一主成分軸は，そ の固有ベクトルが，2つのフレーバー成分を除く全てが プラス值を示していたことから，総成分量が影響してい ると推測された。一方，第二主成分軸は，テルピネンー 4-オール， $\alpha$ オルピネオールがプラスの比較的高い固 有ベクトル值を示すことから，これらの成分が影響して いるものと推測された。

このように第二主成分に対して寄与が大きいテルピネ

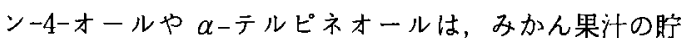

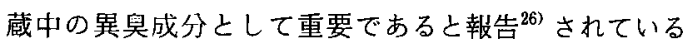
成分である。

\section{3. 解析結果と官能評価との関係}

本研究では比較的上く用いられる2 種の多变量解析法 を使用して，フレーバ一成分と塗膜との関連を調べたが， 最終的な解析の目的は官能的な差と対応した分類を得る ことにある，従来, 食品メ一カーによる官能評価では, 溶剂タイプの塗料から水性タイプの塗料への移行期にフ レーバーの官能的な質の違いが指摘されてきたが，本研 究で用いた 2 種の解析法が共に従来の官能評值と一致し た傾向を示したことは興味深い結果であった。

\section{4. フレーバー成分とアルミ板塗膜との相互作用}

フレーバー変化の原因としては, 喜器材料の一つであ る塗膜へのフレーバー成分の収着, 蓉器材料や容器材料 から溶出した成分とフレーバー成分との相互作用等 ${ }^{33 \sim 5}$
が考えら扎る、フレーバー成分の塗膜への吸着について 筆者らが则途調査したところ，Fig. 5 に示すように， 鋈料形態が溶剂タイプの溒膜は水性タイプのものより般に成分を吸着しにくく，中であ溶剂タイプの塩化ビニ ル系の塗膜は特に吸着量が少ないという知兄が得られた。 しかし，成分を吸着しにくい塗膜であっても，溶液中の 残存量を調べると他の社膜に比べて必ずしす多くないこ とや，溶液中には増加傾向のある成分があることから， 成分の吸着のみが成分変化に影響する主要因ではないと 考えられる。

一方, 容器材料または谷器材料から溶出した成分等上 フレーバー成分との相互作用については以下のように考 えられる，本結果において，主成分分析による分類に寄 与したのはテルペンアルコール量であった。 テルペンア ルコールの果汁中の生成反応としては，リモネン， $\beta$ ピネン等のモノテルペン炭火水素加らの水和反応があり， $\mathrm{pH}$ が低い采, 即ち酸触媒下で促進されることが知られ ている ${ }^{2728)}$. 本実験の $\mathrm{pH}$ は 5.3 上比較的高めである

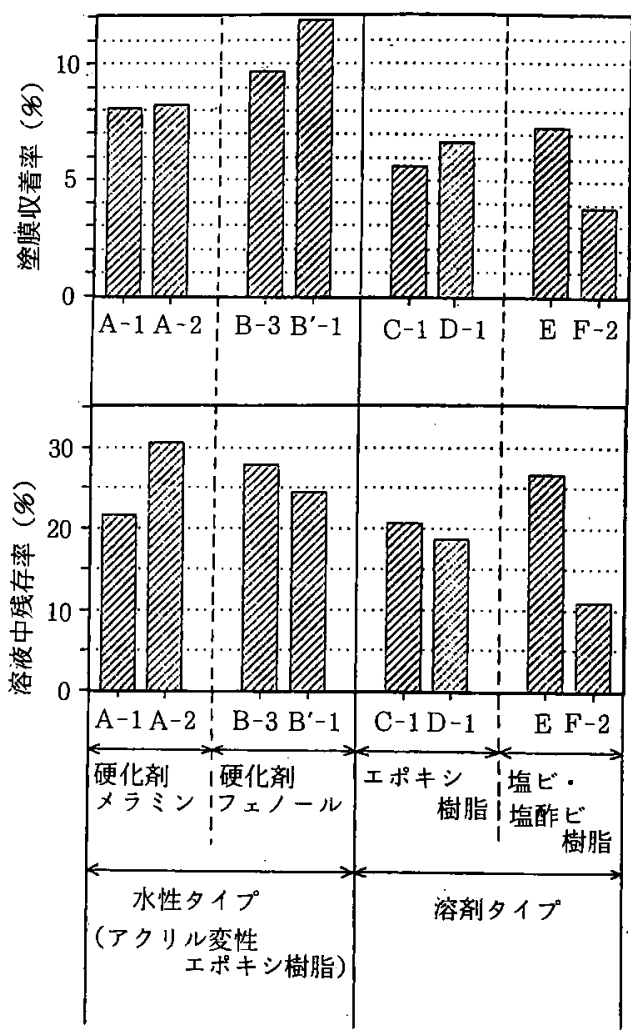

図 5 リモネンの塗膜収着率及び溶液中残存率 


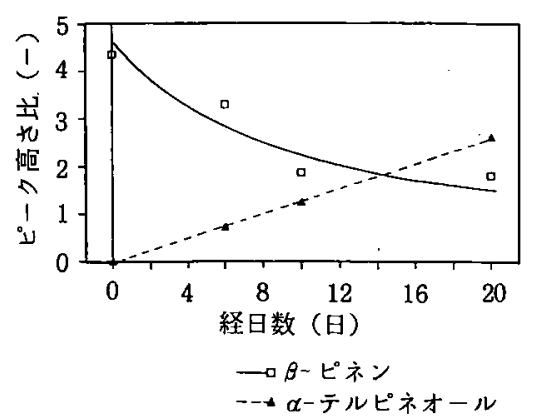

図6 $\beta$-ピネンから $\alpha$-テルピネオールへの変化

が, 別途各フレーバー成分の水溶液を保存して GC-MS にて同定したところ，Fig. 6 に示すように $\beta$-ピネンか $\alpha$-テルピネオールに変化することを確認した.つまり， このような温和な条件下でも，テルペン炭化水素の加水 反応，あるいは溶存酸䒺による酸化によってテルペンア ルコールが生成する可能性がある，しかも塗膜によって テルペンアルコール量に差を生じていることから，容器 材料やそれから溶出した微量成分がそのような反応に対 して触媒的に働いていることが推测される。したがって， 塗膜の種類によってその触媒作用が抑制あるいは促進さ れることにより、テルペンアルコール量に差が生じ，ひ いては官能的な差がすたらされたものと考えられる。

しかしながら，本研究で用いた分析デー夕は個々のフ レーバー成分の官能に対する寄与を無視しているため, 各成分に重み付けをした上でさらに詳細な奏験を行い， 機器分析と官能検查による結果を照合させていく必要が あると思われる。

\section{要約}

種々の現行缶内面堑膜とレモンフレーバーとの関連を 調べることを目的とし，以下のような分析及び統計解析 処理を行った．塗膜を浸漬したレモンフレーバー溶液を 加熱殺菌処理後, $25^{\circ} \mathrm{C}$ で一週間遮光保存したものにつ き，ポリマービーズを用いた吸着法により，溶液中のフ レーバー成分を回収し，GC-MSにより定量分析を行 った，得られた 17 成分のピーク面積比に対して，クラ スター分析と主成分分析を適用したところ，次のような 結果を得た。

1）クラスター分析では, 深料形態が水性タイプの準 膜サンプルグループと溶剂タイプの塗膜サンプルグルー プにほぼ分類された。

2）主成分分析では，溶郕タイプと一部の水性タイプ
の塗膜サンプルグループと水性タイプの塗膜サンプルグ ループとにほぼ分類された。

こうして得られた慗膜タイプ別の分類は官能評価によ り質の違いが指摘されてきた事実と一致した。 さらに主 成分分析でグループ化される主要因となった第一主成分 軸には，みかん果汁の貯蔵中の異臭成分として重要であ るといわれているテルピネンー4-オールや $\alpha$ ーテルピネ オールの量が寄与していた

本研究を行うにあたり，ご指導頂いた九州大学農学部 筬島豊教授，また，試料を提供下さり，適切なアドバイ スをして頂いた小川香料株式会社，堀内哲嗣郎様に厚く 感謝いたします。

\section{文献}

1）小林誠七・渡辺狭樹：塗装技術，24，80（1985）。

2) : Bevarage Japan, 14, 36 (1991).

3) Cabezudo, M.D., Raurich, M.G., Geglero, M, Herraiz, G., Garcia-Dominguez, J.A. and Fernandez-Sanchez, E. : The Shelf Life of Foods and Beverages, G. Charalambous, (Elsevier Science Publishers B.V., The Netherlands), p. 501 (1986).

4) Brody, A.L.: Prepared Foods, 158, 128 (1989).

5）高橋誠一・大関一男 -甲谷明忠: 塗装工学, 23, 189 (1988).

6) Power, J.J. and Keith, E.S.: J. Food Sci. : 33, 207 (1968).

7) Gianturco, M.A., Biggers, R.E. and Ridling, B.H. : J. Agric. Food Chem., 22, 758 (1974)

8) Noble, A.C., Flath, R.A. and Forry, R.R.: J. Agric. Food Chem, 28, 346 (1980).

9) Aishima, T. : J. Food Sci., 47, 1562 (1982).

10) Kwan, W.O., Kowalski, B.R. and Sogerboe, R.K.: J. Agric. Food Chem., 27, 1321 (1979).

11) Schreier, P. and Reiner, L. : J. Sci. Food Agric. : 30, 319 (1979).

12) Leegwater D.C. and Leegwater, J.A., : J. Sci. Food Agric. : 32, 1115 (1981).

13）相島鐵郎：農化， 57，235（1983）.

14）木村良臣・橋本直樹 - 長島義明・吉岡和夫 : 農化, 61, 793 (1987)

15）和田浩二・田中慶教 -下田満哉・大釜清一・第島 豊: 農化, 63, 1485 (1989).

16）和田浩二・田中慶教・下田満哉・大釜清一・筬島 
豊：農化，63，1493 (1989).

17) Wada, K., Ohgama, S., SASaki, H., Shimoda, M. and Osauima, Y.: Agric. Biol. Chem., 51, 1745 (1987).

18) Wada, K., Ohgama S., SAsaki H., Shimoda, M. and Osajima, Y.: Agric. Biol. Chem., 51, 1753 (1987).

19) Harayama, K., Hayase F. and Kato, H. : Agric. Biol. Chem., 55, 393 (1991).

20）杉沢 博・武田 守・楊 栄華・高木信雄 : 日食 工誌, 38, 668 (1991).

21）筬島 豊: FOOD PACKAGING, 29, 80 (1985).

22）下田満哉・平野好司・䇤島 豊: 分析化学, 36 ,
792 (1987).

23）木下栄蔵：多变量解析入阿，(啓学出版，東京）, p. 89 (1987).

24）奥野忠一・久米 均・光賀敏郎・吉澤 正: 多変 量解析法 (日科技連, 東京), p. 391 (1971).

25）パソコン統計解析ハンドブック II 多変量解析 編：(共立出版, 東京), p. 160 (1984).

26）下田満哉・古川太・三宅正起 - 筬島 豊 : 農化, 55, 23 (1981).

27）下田渾哉・筬島 豊: 農化, 55, 491 (1981),

28）下田満哉・筬島 豊：農化，56, 27 (1982)。 (平成 3 年 12 月 20 日受理) 